\title{
Analysis of Role Transformation of Teachers in Marketing Major in Big Data
}

\author{
Xiuhai Li, Haiyan Miao \\ School of Business, Shandong Yingcai University, Jinan 250104, China
}

Keywords: big data; marketing; teacher; role transformation; measures

\begin{abstract}
With the rapid development of Internet technology, big data began to infiltrate in people's work and daily life, affecting people's way of life, thinking form and working mode and so on. Big data can provide more effective and scientific teaching methods for teachers. The first part of this paper describes the significance of marketing in big data era, and the impact on the teaching of marketing major. The second part analyzes the problems of traditional marketing major under the background of big data, and the impact of the arrival of big data era on traditional marketing major. Finally, in order to adapt to the development of big data era, this paper puts forward specific measures to transform the role of professional teachers, hoping to help students effectively improve their marketing level.
\end{abstract}

\section{The Impact of Big Data on Marketing Major}

In the context of the era of large data, all walks of life have been affected to a certain extent, and have a profound impact on the way of education. In recent years, the development of marketing major is very fast. The content of professional knowledge is more and more abundant, and the professional connotation is becoming more and more profound. In order to adapt to the development of marketing, the teaching content of marketing should also be changed. Therefore, the teaching content of marketing major will be rewritten with the change of marketing major[1].

First of all, the marketing tactics have changed, which requires the marketing major to make corresponding measures. In the background of large data, the strategy of marketing has been greatly shortened, and the marketing strategy can be changed in a moment. At this time, the strategic measures of marketing need to be adjusted in time according to the information analysis of large data, and the strategic measures and professional content should be flexible and changeable. Marketing professional teaching content should fully reflect the characteristics of the big data era, and marketing strategy technology will keep pace with the times, and teaching content will also be able to keep pace with the times. Secondly, in the era of big data, the means of marketing are becoming more and more rich. The feature of large data is that the data information is huge. People can analyze the situation according to the changing data information and make corresponding solutions. Based on the characteristics of big data, marketing can break the traditional marketing concept, innovate and develop marketing methods, constantly enrich its marketing means and keep pace with the era of big data. Finally, the era of big data has promoted the refined development of marketing products. Under the background of big data, many products begin to develop towards refinement. Different brand ideas are more and more profound, and service means become personalized. So, marketing should be developed according to the change of brand, improve the pertinence of marketing constantly, and promote the scientific development of marketing system. In the background of the big data age, the information quality is more and more accurate except for the huge amount of data. Therefore, the marketing system has also undergone great changes. Marketing can promote the scientific development of marketing system through scientific research information. In a word, in the era of big data, it has far-reaching significance for the development of marketing.

\section{The Existing Problems in Traditional Marketing Teaching in Big Data}

In marketing, it is pointed out that an enterprise will take a long time if it wants to make a strategic plan. The strategic planning of an enterprise is a process of managing the society. It has a 
comprehensive, essential, long-term and directional planning, which takes a lot of time and energy to solve things. In traditional teaching content, marketing teachers often want to teach students long-term market experience and so on, so that students can better solve business marketing problems after entering the society. However, in the era of big data, if a company makes long-term strategic planning, there is no sense. If a company develops long-term strategy in big data, it will not solve the problem immediately. Therefore, the traditional marketing strategy at this time is impacted, and it needs to be redrawn for the time of marketing strategy.

The important way of marketing is communication, and advertising is the most important way. It is obvious that the power of advertising has been weakened. The traditional way of marketing is television advertising, and today is the era of big data, and a simple two-dimensional code can solve a lot of things.

In the big data era, in the process of marketing professional teaching, the traditional marketing strategy is very difficult to keep pace with the times, if not timely update the marketing strategy, marketing connotation not walk in the forefront of the times, marketing will lose the most important significance.

In traditional classroom teaching, teachers usually teach and students listen. Teachers only use simple teaching tools to teach students a single way of inculcation. In this process, the language communication and emotional communication between teachers and students, and so on, have been limited, and have not played a better role. In the era of big data, there are more and more channels for students to obtain information. The traditional teaching methods can not meet the students' learning requirements. The students are seeking more individualized teaching methods and new teaching contents, which is a great impact on the traditional teaching methods. At the same time, professional teachers are also facing great pressure of teaching, and the teaching content of marketing needs to be changed.

Marketing research is the ways and means of marketing for the enterprise in the market, however, the era of big data market information change constantly in the face of traditional enterprise Internet technology and so on have a lot of impact, if there is no time to make a change, the advantages of traditional marketing methods become increasingly obvious. In the era of big data, business mode has been changed, so marketing concept, marketing strategy and so on also need to change, which has a great impact on the teaching content of traditional marketing.

\section{Measures to Optimize Teaching Methods in Big Data}

With the advent of the era of big data, great changes have taken place in education, which also plays a great role in the change of teachers' role. In the traditional way of teaching, teachers have been using their own test data, their own observation data obtained from students, and parents' understanding of students' data. These data are one-sided and lack a comprehensive understanding and analysis of the students. However, in the era of big data, teachers can make full use of these data to observe students in many ways in order to make the most effective teaching methods and teaching activities and promote the all-round development of students in the era of big data[3].

On the one hand, under the background of big data era, professional teachers of marketing should give full play to their guiding role as a leader in the way of becoming a student. The content of classroom teaching activities, popularly speaking, is that teachers share their learning experience with students, teach knowledge content, lead students to experience learning process in the classroom and receive knowledge content. In the face of the big data age, the teaching methods of marketing, teachers can not be conservative, should be all aspects of the education of students. Big data provides a broader thinking space for teaching content marketing, professional teachers in the teaching process, it should be from the all-round, multi angle to look at the problems in teaching, for marketing content to keep sharp, not absolute knowledge, should be flexible use of classroom knowledge, continue to receive new the information, more timely marketing knowledge to transfer to the students. At the same time, some marketing knowledge strategies require teachers to guide students to explore their own ways, while teachers should give full scope to their students' experience and maximize their own auxiliary functions. 
On the other hand, in the large data background, teachers should be partners to explore the problem and also be the help of the students. The cooperative learning between teachers and students is not only for the cooperation of all the students, but also should pay more attention to specific guidance to individual students. Each student's birth environment, growth experience and so on, there are certain differences. Teachers should teach students in accordance with their aptitude so as to ensure that each student is directed by the teacher. At this time, teachers should give full play to their other functions and organize their functions. We should not only organize classroom activities, but also organize teaching resources, so that students can better accept the teaching contents of marketing in effective teaching resources.

In the background of the era of big data, the role of teachers is becoming more and more important. In this hand has a mobile phone or computer era, students are very easy to be some is not conducive to their own development information deluded, then the teacher should give full play to the leading role of leading students to a meaningful way of life, and promote the healthy development of students. Knowledge of the contents of marketing in the era of big data, is becoming more and more rich and colorful, many students face data will be too busy to attend to all at a loss, at a loss. Teachers are important to promote the growth of students. With the rapid development of Internet technology, students need to communicate with teachers and their inner feelings. For a long time, in the face of a computer screen or a mobile phone screen, the students' feelings are becoming weaker and weaker over time. Marketing is actually the process of communication and communication with people in the market. If students' emotional expression is not enough, they will also affect the marketing effect. Therefore, when marketing knowledge is transmitted, teachers should not only make full use of the characteristics of the big data era, but also pay more attention to the students' inner feelings [4].

In the era of big data, the huge information resources have promoted the development of teaching to some extent. The era of big data is characterized by huge amount of information. Therefore, teachers should constantly teach classroom contents, optimize classroom teaching methods, and give full play to the role and advantages of modern educational technology in marketing teaching. Teachers should change the one-way input teaching mode, make full use of the characteristics of the big data era, and create a two-way or multi-directional classroom interaction teaching method. Teachers should highlight the main body of the students in the classroom and improve the students' ability to use the content of large data information. Under the background of big data era, because of the huge information resources and the limitation of classroom teaching time, many information can not simply rely on teachers to explain for students. At this time, teachers need to transform teaching methods, and guide students to do data collection, data analysis and self integration information resources autonomously. At the same time, they also form good habits of students' autonomous learning. In a word, the teacher in the process of marketing teaching, must give full play to the characteristics of the big data era, grasp the opportunities of the times, constantly for marketing teaching and innovative teaching methods, enrich classroom content, increase classroom teaching activities, improve teaching efficiency, grasp the market marketing strategy so as to promote the students better [5].

Big data era, teachers should change the traditional teaching concept, teaching methods can still uphold the traditional indoctrination, the teacher centered traditional teaching method the teacher, students listen to, has been unable to meet the development needs of the times. Teachers should make full use of modern education science and technology, so that students can truly learn marketing knowledge and explore marketing strategies and means. In the course of teaching, teachers should fully mobilize the enthusiasm of the students so that students can participate in the teaching activities. Teachers should give full play to their guiding role, so that the main position of the students should be reflected in the teaching and improve the quality of classroom teaching [6].

In the traditional marketing professional teaching content, many sources of teaching resources are textbooks, related professional books, and many business case data collected by teachers, etc., the source is too narrow, which is not conducive to students' full reception of information. In addition, many objective factors are limited, for example, teaching facilities are not complete and so 
on, and many of the information that can be provided to the classroom is limited. But in the big data environment, teaching information resources are very rich. Teachers can make full use of these information resources, and interact with students in marketing classroom teaching, so that students can actively participate in classroom activities. In the era of big data, teachers should make full use of these favorable technological conditions and information conditions to transform from traditional teacher centered teaching status to students oriented. Teachers should also use all kinds of interesting teaching methods to explore more teaching methods that can arouse their enthusiasm and improve their interest in learning. Adhere to the student-centered teaching concept, the teaching activities more interesting, vivid, vivid, digital, real use of big data to achieve personalized teaching, change their role of education, improve teaching quality, promote the all-round development of students.

\section{Conclusion}

Nowadays, the development of information technology and Internet technology is more and more rapid, which deeply affects people's daily life and work content and learning methods. In the face of the advent of the era of big data, the teaching content and methods of marketing have also changed greatly. Teachers are an important driving force to promote human civilization, and shoulder the responsibility of cultivating the motherland for generations for young people, and the role and significance of teachers are important. Therefore, in order to conform to the trend of the times and meet the requirements of the big data era, teachers should transform their identity roles, actively transform the traditional teaching understanding, and innovate the teaching contents of marketing. In the process of teaching, teachers innovate and develop marketing teaching methods according to the characteristics and modes of big data era, and are committed to transform modern science and technology into effective resources in marketing professionals. It can not only improve the quality of classroom teaching, cultivate professional talents in marketing, but also promote the modernization process of our motherland, and finally, improve our comprehensive competitiveness.

\section{Acknowledgements}

Fund Project: 2015 Shandong Province undergraduate teaching reform research project (2015M176)

\section{References}

[1] Cuevas J M. The transformation of professional selling: Implications for leading the modern sales organization[J]. Industrial Marketing Management, 2018.

[2] Chaoju H U. Leading Big Data: Operational and Marketing Transformation Strategy of Chinese Commercial Banks[J]. Journal of Chongqing University of Posts \& Telecommunications, 2017.

[3] Montgomery K, Chester J, Nixon L, et al. Big Data and the transformation of food and beverage marketing: undermining efforts to reduce obesity? [J]. Critical Public Health, 2017(1):1-8.

[4] Cuevas J M. The transformation of professional selling: Implications for leading the modern sales organization[J]. Industrial Marketing Management, 2018.

[5] Li J. Research on the Transformation of Internet Banking and Commercial Bank's Retail Marketing Service[J]. Reformation \& Strategy, 2017.

[6] Eberhard B, Podio M, Alonso A P, et al. Smart work: The transformation of the labour market due to the fourth industrial revolution (I4.0) [J]. International Journal of Business \& Economic Sciences Applied Research, 2017, 10. 